\title{
Ecologically Safe Architecture of Agrolandscape Is Basis for Sustainable Development
}

\author{
Ekaterina G. Kotlyarova ${ }^{1}$, Vladimir I. Cherniavskih ${ }^{2} \&$ Elena V. Dumacheva ${ }^{3}$ \\ ${ }^{1}$ Department of Agriculture and Agrochemistry, Belgorod State Agricultural Academy, Belgorod, Russia \\ ${ }^{2}$ Botanical Garden, Belgorod State University, Belgorod, Russia \\ ${ }^{3}$ Department of Tourism and Socio-cultural Service, Belgorod State University, Belgorod, Russia \\ Correspondence: Ekaterina G. Kotlyarova, Department of Agriculture and Agrochemistry, Belgorod State \\ Agricultural Academy, Belgorod, Russia. Tel: 7-472-239-2554. E-mail: kotlyarova@bel.ru
}

Received: August 8, 2012 Accepted: November 11, 2012 Online Published: November 25, 2012

doi:10.5539/sar.v2n2p11 URL: http://dx.doi.org/10.5539/sar.v2n2p11

\begin{abstract}
Worldwide, about $12 \times 10^{6}$ ha of arable land are destroyed and abandoned annually due to soil erosion. This problem is very serious for Krasnogvardeiskiy district, which is most eroded district (72.7\% eroded lands) in the Central Chernozem Zone (CCZ) of Russia. Under the leadership of the academician of Russian Academy of Agrarian Sciences O.G. Kotlyarova the landscape agricultural systems (LASs) were mastered throughout the Krasnogvardeisky district (132 thousand ha). Our investigations showed that the purpose for which LASs were created is reached. Obtained results showed that it is possible to prevent erosive losses and to raise soil fertility. Restoration of soil fertility is presented in terms of increasing of crops productivity-on $25 \%$. Transformation of a landscape basis has increased the general biological capacity of territory more than twice and exchangeable biological capacity by $32 \%$. All these facts have raised assimilability of the transformed territory that allows to consider it, unlike traditional, not as source $\mathrm{CO}_{2}$ in atmosphere, and as fixed carbon tank which capacity can reach $0,71 \mathrm{t} / \mathrm{ha}$. In turn the intensification of substances circulation leads to increasing of plant production efficiency. Excess is from $14 \%$ (productivity of labour expenses) to $43.2 \%$ (use efficiency of PAR). In intensively mastered agricultural district (arable lands more than 80\%) agroecosystems have been formed, allowing besides its basic function: soil preservation, steady reception of agricultural production, to carry out also the major biospheric function - increasing biological variety, creation of a favorable inhabitancy for live organisms, including human.
\end{abstract}

Keywords: landscape agricultural systems, environment, sustainable agriculture, erosion

\section{Introduction}

Reaching the purpose of getting maximum amount of interest in products, people and their activity leads to drastic contraction of landscape's general productivity (biomass) volumes; this fact is associated with a reduction in landscape's ability to withstand the destructive influence of the factors leading to its degradation. The example of deregulation of agroecological systems is an intensive development of erosive processes as a result of implementation of non-adaptive farming systems to local landscape conditions. According to UNESCO (Lal \& Stewart, 1990), the main share in the soil's destruction belongs to water erosion and deflation, and form $84 \%$. Worldwide, about $12 \mathrm{mln}$. ha of arable land are annually destroyed and abandoned because of nonsustainable farming practices. During the last 20 years rates of eroded land's growth in Russia have being reached 6-7\% every 5 years, i.e. up to $1.5 \mathrm{mln}$. ha per year (Romanenko, 2007).

For the Belgorod region this problem is very serious where the slope lands are $72 \%$. This is the most eroded region of Central Chernozem zone where the share of lands subjected to erosion is $53 \%$, two times more than the average for Central Chernozem zone (28\%). The most eroded district in Belgorod region is Krasnogvardeiskiy ( $72.7 \%$ lands eroded; soils losses were classified as "catastrophic").

Myers (1993) reports that approximately 75 billion tons of fertile soil are lost from world agricultural systems annually. Together with the soil up to $30-50 \%$ of fertilizers and pesticides disappear irrevocably because of water erosion and deflation, and they not only disappear, but also pollute the environment, particularly water and air. Damage from soil erosion worldwide is estimated to be $\$ 400$ billion per year (Pimentel et al., 1995). 
It is impossible to stabilize soil fertility, to prevent further deterioration of water resources without excluding of any form of erosion. The necessity of conducting agriculture on the basis of laws of functioning natural ecosystems and landscapes was realized. The landscape agricultural systems (LASs) became the systems of a new generation. It is necessary to create such agrolandscape architecture that it possessed the greatest ecological capacity and still maintain the maximum degree of its social mission.

Ability of ecosystem to withstand human impact (including pollution) is defined as the capacity of ecosystem. Ecological capacity of the territory as a natural complex is defined by capacities of main natural resources and intensity of flows, renewing these resources (Milashchenko, Sokolov, Bryson, \& Chernikov, 2000). Like natural ecosystems, the sustainability of agriculture ecosystems is determined by biotic component and is characterized by their productivity, which is both a response and a measure of stability. The level of productivity depends on the ecological activity of the area, i.e. intensity and volume of small biological cycle of matter and energy flows, which is the highest and efficiently with maximum environmental capacity (Volodin, 2000).

Increasing the energy level of agroecosystem and its stabilization is the main task of agricultural production, a decision which is achieved by optimizing the use of ecological capacity of agrolandscapes. One of the most actual tasks for society and science is to optimize use of natural and anthropogenic resources and management of agrolandscapes evolution on the way of noogenesis based on effective screening and monitoring approaches, planning and forecast of anthropogenic impact on biosphere consequences. In order to reach these aims it is necessary to study in details peculiarities of stable agrolandscapes formation. The paper aims at reviewing the functional roles of landscape agricultural systems in improving the environmental performance of agro-ecosystems in terms of soil preservation, stability of agricultural production, increasing biological variety, creating a better environment for a large number live organisms, including human beings.

\section{Material and Methods}

\subsection{Description of Study District}

Landscape agricultural systems development in Krasnogvardeiskiy district has been started in 1981. Average loss of humus layer reached almost $1 \mathrm{~cm}$ per year - it is many times more than intensity of soil formation process. In most critical situations because of top fertile layer loss affected by erosion desertification process there was observed. If one couldn't prevent such development intensity of soil's erosion, large lands would be lost for agriculture production by 2000 year. That's why this district was chosen for landscape agricultural systems development.

The great contribution in working out theoretical bases of landscape agriculture was brought by the academician of Russian Academy of Agricultural Sciences O.G. Kotlyarova, under her guidance a large-scale development of landscape agricultural systems was carried out in Krasnogvardeiskiy district of Belgorod region (Figures 1 and 2).

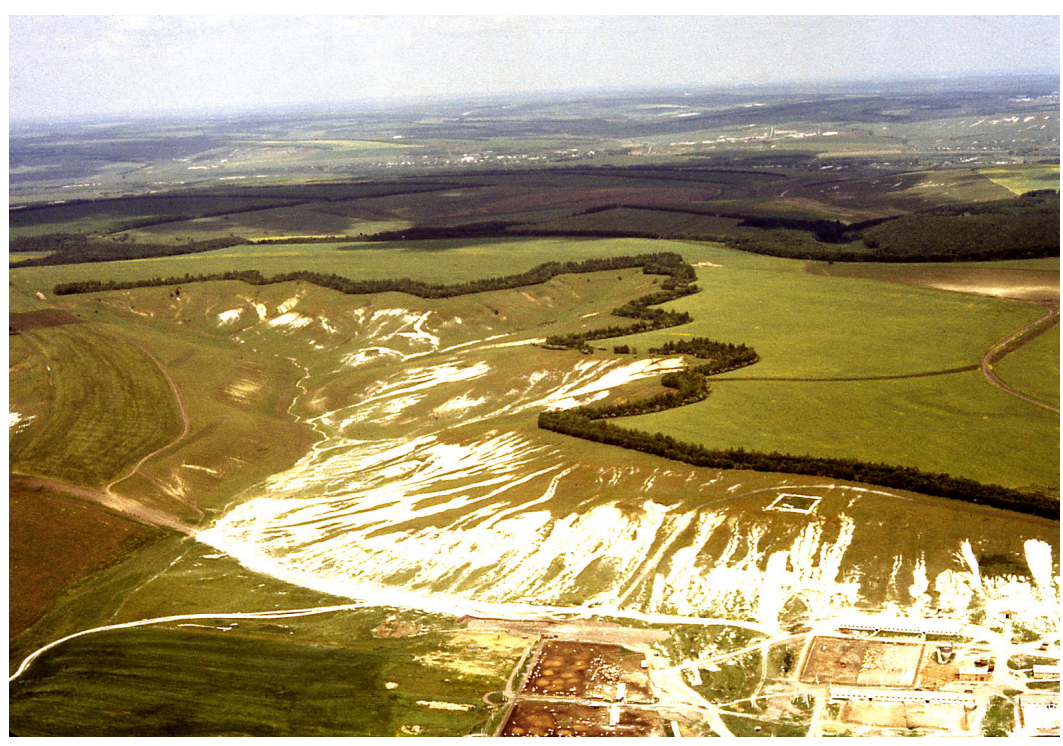

Figure 1. Before development of landscape agricultural systems (1979) 


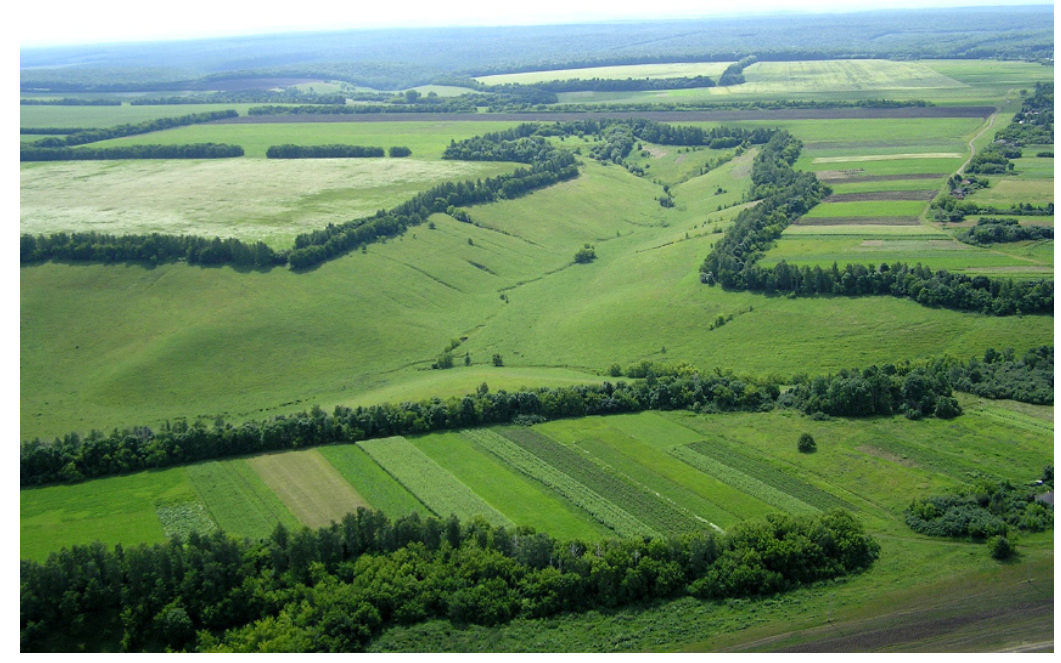

Figure 2. After development of landscape agricultural systems (2008)

The landscape agricultural system's elements are an organization of land-use, differentiated location of crop rotation of different soil protection direction, soil protection technologies of crops and systems of machines, forest improving, meadow-improving, hydraulic and other activities. The key moment and the basis for the whole complex of soil protection activities become erosion-preventive territory organization, as it includes territory typification and marking of agrolandscape stripes by homogeneous agriculture ecological conditions, erosion rates, angle slope and pattern of use. Allocated agrolandscape strips characterize 4 modules of landscape agricultural systems: intensive (intensive technologies, intensive crop rotations with saturation of row crops, intensive sorts, etc.), soil protective (excluding the use of row crops), biological (with the saturation of perennial grasses from 50 to $100 \%$ ) and remediation (solid grassing, continuous afforestation, flattening of the ravine, etc.).

In total district, on the area of 132 thousand hectares (including 92.5 thousand hectares of arable land) 8700 hectares of forest plantations were planted, including 1763 ha of shelter and water regulation, 5520 ha of gully-beam, 157 ha of riverside, 1229 ha of solid afforestation. Over the years of the system development the existing gully tops were fixed, there were constructed in total 315 walls, created 121 erosion-preventive ponds, graded a large number of gullies, more than 50 gullies and watercourses were graded and sown by perennial grasses, in general, $20 \%$ of arable land is at perennial grasses (Kotlyarova, 2004).

Krasnogvardeyskiy district, throughout the territory of which as the result of intensive development and the active positive impact of all the elements of landscape agricultural systems has created a high resistance natural-anthropogenic complex that is a good example of the transformation of agrolandscapes and environmental enrichment.

\subsection{Methodology and Methods}

The methodological basis of our study was a comparative analysis of crop and agrolandscape's productivity of three neighboring south-eastern districts of Belgorod region-Krasnogvardeyskiy (with complete development of all elements of LASs in the entire territory of the district), Valuiskiy and Veidelevskiy districts (without the full development of landscape agricultural systems, which are mastered fragmentarily, at individual farms). As crop yields comparison in landscape agricultural systems before and after development, as is usually done in this type of research (Models, 2005), may not be entirely correct, since in this case, the variability of this indicator is strongly influenced by factors such as weather conditions, scientific and technical progress, agricultural policy, etc.

For evaluation of agrolandscape productivity data of statistical annual reports of Agroindustrial department of Belgorod Government were used in order to obtain information on crop yield and acreage structures of 3 neighboring district for 30 years period (1981-2010). By-product, vegetation and root residues were determined with the help of equation of regression (Volodin, 2000). Organic mass quantity of grass vegetation of forest cenosis was considered based on above-ground phytomass (sample areas $1 \mathrm{~m}^{2}, 6$-time replication, random in 30 forest strips). Value of vegetation associations' biomass was considered in the period of maximum phenological 
development when in reproductive period not less than $80 \%$ of plants were transferred. The quantity of woody vegetation organic mass - by determining of mean tree parameters (Losovoy, 1996). Based on established by Karpachevskiy (1981) relations the mass of tree's main parts was estimated. The evaluation of agrolandscapes bioenergy potential was carried out with "Methods of resourse-ecological estimation of farming efficiency on bioenergy basis" (Volodin, Eremin, Fedorchenko, \& Ermakova, 1999). This source contains for study zone all necessary reference and normative materials using which as well as the results of our study following indicators were calculated:

BEPT - bioenergy potential of territory:

$\mathrm{BEPT}=\left(\mathrm{E}_{\mathrm{sp}}+\mathrm{E}_{\mathrm{ag}}\right)+\left(\mathrm{E}_{\mathrm{som}}+\Delta \mathrm{E}_{\mathrm{s}}\right), \mathrm{GJ} / \mathrm{ha}$,

where $\mathrm{E}_{\mathrm{sp}}$ - energy store of general phytomass (above- and underground);

$E_{a g}-$ annual energy gain of phytomass;

$\mathrm{E}_{\mathrm{som}}$ - energy store of soil organic matter (soil power potential) (soil layer 0-20 cm);

$\pm \Delta \mathrm{E}_{\mathrm{s}}$ - gain and fall of energy of soil organic matter (soil layer 0-20 cm).

Energy efficiency of photosynthetic active radiation (PAR) by agroecosystem over a crop season:

$$
\mathrm{I}_{\mathrm{PAR}}=\left(\mathrm{E}_{\mathrm{ph}} \pm \Delta \mathrm{E}_{\mathrm{s}}\right) / \mathrm{E}_{\mathrm{PARvp}}
$$

where $\mathrm{E}_{\mathrm{ph}}$ - energy output aboveground phytomass, $\mathrm{mJ} / \mathrm{ha}$. This value determines by yield of aboveground plant phytomass ( $\mathrm{kg} / \mathrm{ha})$, energy content in dry matter $(\mathrm{mJ} / \mathrm{kg}$ ) and dry matter content in yield biomass (fractions);

$\mathrm{E}_{\text {PARvp }}$ - energy of photosynthetic active radiation over a vegetation period, $\mathrm{mJ} / \mathrm{ha}$.

Energy efficiency of soil organic matter:

$$
\mathrm{I}_{\mathrm{som}}=\left(\mathrm{E}_{\mathrm{ph}} \pm \Delta \mathrm{E}_{\mathrm{s}}\right) / \mathrm{E}_{\mathrm{som}},
$$

where $\mathrm{E}_{\mathrm{som}}$ - energy of soil organic matter, $\mathrm{mJ} / \mathrm{ha}$.

Total anthropogenic energy efficiency:

$$
\mathrm{I}_{\mathrm{A}}=\left(\mathrm{E}_{\mathrm{ph}} \underline{\underline{A}} \mathrm{E}_{\mathrm{s}}\right) / \mathrm{E}_{\mathrm{A}},
$$

where $\mathrm{E}_{\mathrm{A}}$ - total anthropogenic energy losses, $\mathrm{mJ} / \mathrm{ha}$.

Agriculture ecosystem capacity index per monetary expenses:

$$
\mathrm{P}_{\mathrm{m}}=\left(\mathrm{E}_{\mathrm{ph}} \pm \Delta \mathrm{E}_{\mathrm{s}}\right) / \mathrm{M}_{\mathrm{e}} \cdot \mathrm{T}_{\mathrm{vp}}
$$

where $\mathrm{M}_{\mathrm{e}}-$ monetary expenses, rub./ha

$\mathrm{T}_{\mathrm{vp}}-$ vegetation period, days.

Agriculture ecosystem capacity index per labor expenses unit:

$$
P_{1}=\left(E_{p h} \pm \Delta E_{s}\right) / L_{e} \cdot T_{v p},
$$

where $\mathrm{L}_{\mathrm{e}}$ - labor expenses, per.-hour./ha.

\section{Results and Discussion}

\subsection{Vegetation Biodiversity and Soil Fertility}

Previous our studies have shown a significant expansion of vegetation biodiversity in the environmentally sustainable agroecosystem transformed by the introduction of a wide range of tree and shrub species in protective forest plantations (PFP), as well as the occurrence of herbaceous flora in PFP. Inventory identified a significant number species, including 15 rare and endangered species of the Belgorod region Red Book (Kotlyarova \& Cherniavskih, 2008).

Soil is one of the most important elements of agrolandscapes, since its structure, nutrients, organic matter, largely determine the primary productivity of agroecosystems. It is characterized by self-purification and the buffering capacity. The most important function of the soil is the generation and conservation of biological diversity. To improve the environmental role of farming systems, it is necessary to preserve the fertility along with the production rates was one of the criteria of economic activities operating on the ground. Agricultural systems is not providing soil protection, can not be considered effective. Well-known techniques to conserve and enhance soil fertility are the use of organic and mineral fertilizers, straw, green manure, perennial grasses, conservation tillage practices, etc. (Shevtsova et al., 2003; Verzilin, 2004; Eskov, Lukin, \& Tarasov, 2005; Cherniavskih, \& Kotlyarova, 2009; Nemtsev, Sabitov, \& Nikitin, 2009; Shelganov, Domanov, Solovichenko, \& Potryasaev, 2009). 
But they will not work in conditions of intensive development of erosion processes.

The purpose for which were created landscape agricultural systems is reached. They managed not only prevent soil erosion losses, but improve on this basis soil fertility. The rates of increasing of humus content throughout the Krasnogvardeisky district are $0.02 \%$ (abs.) per year, and in some cases, they reach $0.05 \%$ or more in a year. According to the regional agrochemical service humus content in the last twenty five years increased from $4.8 \%$ to $5.2 \%$ (Figure 3 ).

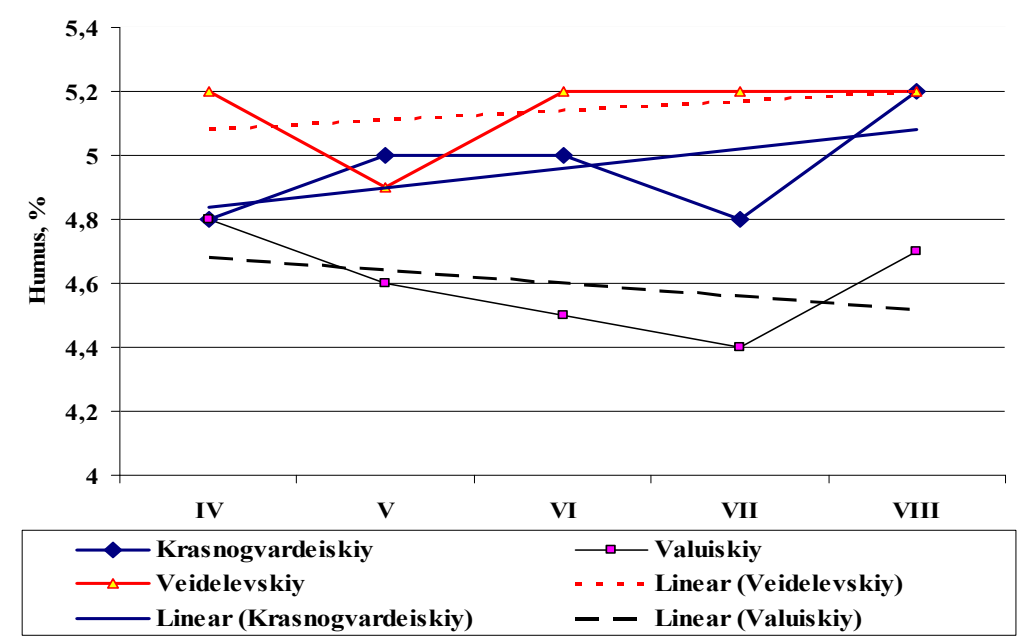

Figure 3. Soil characteristic on humus content (\%) as the result of agrochemical inspection rounds done by Federal State Institution "CAS "Belgorodskiy" in south-eastern districts of Belgorod region

The excess of modern humus state over the source was more than $8 \%$. This is especially significant when compared with the processes occurring in the soils of the two neighboring districts - Valuiskiy and Veydelevskiy. In the initial period humus content in Valuiskiy district was the same as in Krasnogvardejskiy - $4.8 \%$. But if you are already in the early periods of development of landscape agricultural systems observed in Krasnogvardejskiy district humus stabilization and its further growth, in Valuiskiy district loss of humus continued. At present, the difference between these districts in humus content consists $0.5 \%$ (abs.). Soil bonitet in Veydelevskiy district was initially higher than in neighboring districts - the humus contents $5.2 \%$. Last round of agrochemical studies revealed no difference between this indicator in Krasnogvardejskiy and Veidelevskiy districts. The observed positive dynamics of humus content in soils of Krasnogvardeiskiy district with even more significant in the analysis of soil erosion of the three districts. Share of eroded and erosive hazard lands comprises $72.7 \%$, whereas in Valuiskiy it was equal to $61.4 \%$, and in Veidelevskiy it was even less - $57.0 \%$ (Figure 4).

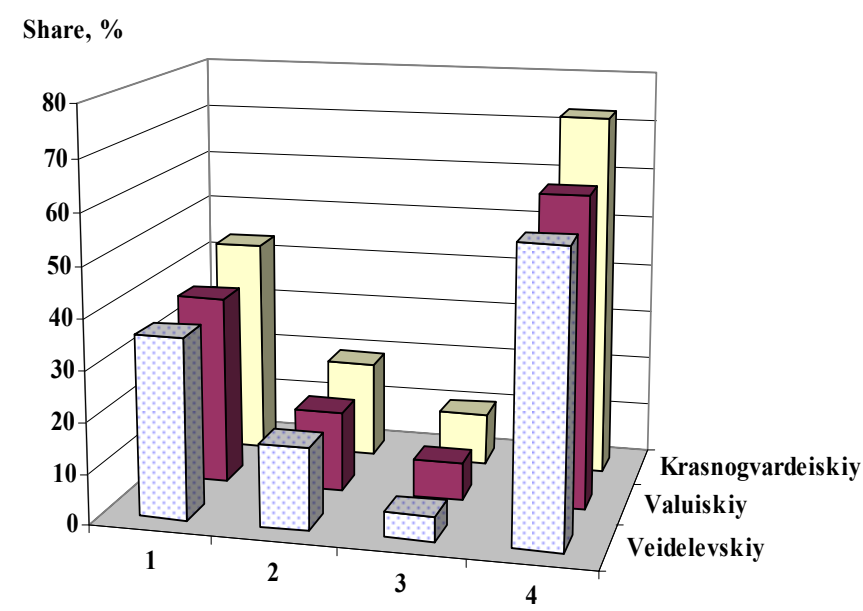

Figure 4. Soil erosional features in south-eastern districts of Belgorod region, \% (acc. Solovichenko, 2005)

1 - slight eroded, 2 - moderate eroded, 3 - severe eroded, 4 - all eroded 
Thus, the preservation and accumulation of humus in soils in the whole Krasnogvardejskiy district indicates a high efficiency of landscape agricultural systems. Change rates of humus content are differentiated depending on the conditions of relief and completeness of the development of landscape agricultural systems.

\subsection{Crop Yield in Transformed Agrolandscapes}

Restoring soil fertility at the development of LASs is reflected in increasing crop yields. For estimation of the influence of landscape agricultural systems since 1981, the beginning of their development on the farms of Krasnogvardeiskiy district, yield record of cereal and other crops was taken in three neighboring districts: Valuiskiy, Veydelevskiy and Krasnogvardejskiy. Such a comparative analysis appeared to be the methodological basis for our research. Crop yields comparison before development of landscape agricultural systems, and after, as it is usually done in the scientific literature (Models, 2005), as already noted, may not be entirely correct, in this case the variability of this indicator is strongly influenced by factors such as weather conditions, technological development and agricultural policy.

In order to maximize the possible exception of these factors impact on the variability of crop yields, this indicator was analyzed in three neighboring districts. Valuiskiy and Veidelevskiy districts were chosen for comparison analyses for a reason.

- All three studied districts located in similar climatic conditions (Atlas, 2005). It should be noted as a key factor - erosion development - Krasnogvardeiskiy district occurs in more difficult conditions. The share of eroded and erosion hazard lands here is on $11.1 \%$ higher, than in Valuiskiy district and on $15.7 \%$ higher, then in Veidelevskiy district (Figure 4).

- At the beginning of landscape systems development soil conditions were more or less equal. Average humus content in Veidelevskiy district composed 5.2\%, in Valusikiy and Krasnogvardeiskiy districts is $4.8 \%$.

- And most important at the initial period of landscape agricultural systems development in Krasnogverdeiskiy district from 1981 till 1985 level of cereal crops yield was an equal - 1.63-1.67 t/ha (Table 1).

Increasing of agricultural crops productivity in LASs happens not only due to the preservation and improvement of soil fertility, but also due to their adaptive placement in accordance with agricultural land agro-ecological zoning. The key moment of agrotechnics in LASs is the differentiation of crop rotation, which is economically justified because it allows reducing the cost of cultivation by right placing of crops with an increase in croppage. Already in next 5 years Valuiskiy and Veidelevskiy districts became slow in cereal crop yields on 0.2-0.4 t/ha. Till 1996-2000 years these differences reached 0.4-0.6 t/ha, that comprised 20-30\% in comparison with yield in Krasnogvardeiskiy district. On average over the past 25 years, the difference in grain yields in Krasnogvardeiskiy district and two neighboring districts was $0.2-0.4 \mathrm{t} / \mathrm{ha}$.

Table 1. The dynamics of the yield of grain crops in south-eastern districts of Belgorod region for 30 years, $t / h a$

\begin{tabular}{cccccc}
\hline \multirow{2}{*}{ Years } & \multicolumn{4}{c}{ Districts } & \multicolumn{3}{c}{ Fluctuations from Krasnogvardeiskiy district } \\
& Krasnogvardeiskiy Valuiskiy Veidelevskiy & In Valuiskiy & In Veidelevskiy \\
\hline $1981-1985$ & 1.63 & 1.67 & 1.64 & +0.04 & +0.01 \\
$1986-1990$ & 2.87 & 2.44 & 2.55 & -0.43 & -0.32 \\
$1991-1995$ & 2.42 & 2.09 & 2.24 & -0.33 & -0.18 \\
$1996-2000$ & 1.99 & 1.37 & 1.60 & -0.62 & -0.39 \\
$2001-2005$ & 2.32 & 2.09 & 2.55 & -0.23 & +0.23 \\
$2006-2010$ & 2.64 & 2.24 & 2.40 & -0.40 & -0.24 \\
$1986-2010$ & 2.45 & 2.05 & 2.27 & -0.40 & -0.18 \\
\hline
\end{tabular}

Even more significant differences observed in yields on certain crops such as barley, peas, sugar beets, silage corn, grasses, and others (Table 2). 
Table 2. Indicators of productivity of major crops in Valuiskiy and Veidelevskiy districts

\begin{tabular}{|c|c|c|c|c|c|c|c|c|c|c|}
\hline & & & Valuiskiy & & & & & idelevskiy & & \\
\hline Indicators & 1986-1990 & 991-1995 & $996-20002$ & $001-20052$ & 006-20091s & 986-199019 & $991-19951$ & $996-200020$ & $001-200520$ & 006-2009 \\
\hline winter wheat $-\mathrm{Y}, \mathrm{t} / \mathrm{ha}$ & 3.23 & 2.31 & 1.7 & 2.4 & 2.74 & 3.35 & 2.59 & 2.14 & 2.97 & 2.43 \\
\hline $\mathrm{F}, \mathrm{t} / \mathrm{ha}$ & -0.4 & -0.19 & -0.56 & -0.19 & -0.36 & -0.28 & 0.09 & -0.12 & 0.38 & -0.36 \\
\hline $\mathrm{F}, \%$ & 89 & 92.4 & 75.1 & 92.6 & 88.3 & 92.2 & 103.5 & 94.6 & 115.6 & 87.1 \\
\hline $\mathrm{S}, \%$ & 12.4 & 8.2 & 33 & 7.9 & 13.4 & 8.4 & - & 5.6 & - & 14.8 \\
\hline barley $-\mathrm{Y}, \mathrm{t} / \mathrm{ha}$ & 2 & 2.1 & 0.81 & 1.95 & 1.88 & 2.16 & 2.19 & 1.22 & 2.24 & 2.1 \\
\hline $\mathrm{F}, \mathrm{t} / \mathrm{ha}$ & -0.74 & -0.4 & -0.93 & -0.19 & -0.72 & -0.58 & -0.32 & -0.52 & 0.09 & -0.38 \\
\hline $\mathrm{F}, \%$ & 73 & 84 & 46.6 & 91.1 & 72.5 & 78.9 & 87.2 & 69.9 & 104.4 & 84.7 \\
\hline $\mathrm{S}, \%$ & 37 & 19 & 114.5 & 9.7 & 38.2 & 26.8 & 14.6 & 42.7 & - & 18.1 \\
\hline peas $-Y, t / h a$ & 1.76 & 1.75 & 0.88 & 1.34 & 1.44 & 1.9 & 1.77 & 1.01 & 1.85 & 1.4 \\
\hline $\mathrm{F}, \mathrm{t} / \mathrm{ha}$ & -0.43 & -0.45 & -0.27 & -0.14 & -0.36 & -0.29 & -0.43 & -0.15 & 0.38 & -0.32 \\
\hline $\mathrm{F}, \%$ & 80.3 & 79.4 & 76.2 & 90.8 & 80.2 & 86.8 & 80.5 & 92.2 & 125.4 & 81.4 \\
\hline $\mathrm{S}, \%$ & 24.4 & 25.7 & 30.8 & 10.4 & 25 & 15.2 & 24.3 & 14.9 & - & 22.9 \\
\hline sugar beet $-\mathrm{Y}, \mathrm{t} / \mathrm{ha}$ & 23.9 & 15.66 & 13.61 & 21.17 & 28.14 & 28 & 19.5 & 17.48 & 28.69 & 25.15 \\
\hline $\mathrm{F}, \mathrm{t} / \mathrm{ha}$ & -3.6 & -4.82 & -5.4 & -0.69 & -1.74 & 0.5 & -0.98 & -1.53 & 6.83 & -2.55 \\
\hline $\mathrm{F}, \%$ & 86.9 & 76.5 & 71.6 & 96.8 & 94.1 & 101.8 & 95.2 & 91.9 & 131.3 & 90.8 \\
\hline $\mathrm{S}, \%$ & 15.1 & 30.8 & 39.7 & 3.3 & 6.2 & 2 & 5 & 8.8 & - & 10.1 \\
\hline silage corn $-\mathrm{Y}, \mathrm{t} / \mathrm{ha}$ & 22.11 & 14.45 & 11.5 & 15.85 & 14.48 & 21.41 & 15.73 & 13.79 & 17.56 & 14.3 \\
\hline $\mathrm{F}, \mathrm{t} / \mathrm{ha}$ & -6.1 & -5.09 & -5.1 & 0.86 & -2.24 & -6.8 & -3.81 & -2.81 & 2.57 & -1.02 \\
\hline $\mathrm{F}, \%$ & 78.4 & 73.9 & 69.3 & 105.8 & 86.6 & 75.9 & 80.5 & 83.1 & 117.2 & 93.3 \\
\hline $\mathrm{S}, \%$ & 27.6 & 35.2 & 44.3 & - & 15.5 & 31.8 & 24.2 & 20.4 & - & 7.1 \\
\hline perennial grasses $-\mathrm{Y}, \mathrm{t} / \mathrm{ha}$ & 19.62 & 11.39 & 7.43 & 9.56 & 11.59 & 19.92 & 12.84 & 8.47 & 10.63 & 12.89 \\
\hline $\mathrm{F}, \mathrm{t} / \mathrm{ha}$ & -6.66 & -8.64 & -5.17 & -2.22 & -5.58 & -6.36 & -7.2 & -4.14 & -1.15 & -1.83 \\
\hline $\mathrm{F}, \%$ & 74.6 & 56.9 & 59 & 81.1 & 67.5 & 75.8 & 64.1 & 67.2 & 90.2 & 87.6 \\
\hline $\mathrm{S}, \%$ & 34 & 75.8 & 69.5 & 23.3 & 48.1 & 31.9 & 56.1 & 48.9 & 10.8 & 14.2 \\
\hline
\end{tabular}

Y - Yield, F - Fluctuations from Krasnogvardeiskiy district, S - Share of reduction in own yield.

And in the most unfavorable years (1996-2000) reduction in crop yields in Valuiskiy and Veydelevskiy districts compared to Krasnogvardejskiy district was maximum that indicates a higher stability of the landscape agricultural systems, particularly in environmentally stressful conditions. The same trend is apparent in the extremely dry 2010. When in Krasnogvardeyskiy district this year losses of cereal crop planting acres comprises $1.9 \%$ because of draught, then in Valuiskiy and Veidelevskiy districts -27.1 and $9.5 \%$ accordingly. Taking it into account, the difference in grain yield is $0.20-0.59 \mathrm{t} / \mathrm{ha}$.

It should be noted that in recent years in Valuiskiy and Veidelevskiy districts works are in a progress underway on the development of landscape agricultural systems. The intensity of erosion processes is reducing and this creates background for the yield growth, which is reflected in a slight reduction of differences between districts.

\subsection{Productive Potential}

In adaptive-landscape agriculture structure of acreage, and therefore the level of farms specialization can not be violent. The structure of the acreage should provide a highly productive use of tilled fields at an optimal combination of economic and environmental objectives, organically aligned with the all crop rotation system creating conditions for full realization of positive effect on crop rotation.

Landscape approach to the development of optimal structure of acreage supposed increase of tillage differentiation in order to use fully utilize bioclimatic resources of agrolandscape by cultivated plants on the one hand, and accounting of environment restoring features of cultivated plant species on the other.

As the result of photosynthetic assimilation besides main, by-product is formed, as well as plant and root residues, weight control of which is important for providing a complete picture of productive agrolandscapes potential realization. We converted all above- and underground crops phytomass to dry matter in accordance with their share in structure of acreage for correct comparison of territories by total productivity of agrolandscapes in studied districts (Table 3). 
Table 3. Output of dry matter of main product and general crops phytomass on tillage in south-eastern districts of Belgorod region, $\mathrm{t} / \mathrm{ha}$

\begin{tabular}{lccccccc}
\hline \multicolumn{1}{c}{ Districts } & $\begin{array}{c}\text { Type of } \\
\text { production }\end{array}$ & $1986-1990$ & $1991-1995$ & $1996-2000$ & $2001-2005$ & $2006-2010$ & Average for \\
\hline Krasnogvardeiskiy & MP & 3.92 & 2.94 & 2.31 & 2.42 & 2.52 & 2.82 \\
& General & 11.10 & 8.63 & 7.06 & 7.72 & 8.34 & 8.57 \\
Valuiskiy & MP & 3.14 & 2.01 & 1.37 & 2.10 & 2.08 & 2.14 \\
& General & 9.28 & 6.65 & 4.87 & 7.16 & 7.21 & 7.03 \\
Veidelevskiy & MP & 3.14 & 2.22 & 1.65 & 2.52 & 2.35 & 2.38 \\
& General & 9.59 & 7.24 & 5.68 & 8.25 & 7.73 & 7.70 \\
\hline
\end{tabular}

Note: MP - main product; General, including main product, by-product, plant residues, root residues.

It should be noted that in recent years in Valuiskiy and Veydelevskiy districts the share of the most productive areas with row crops has increased sharply-on 52 and $77 \%$ respectively, which is about 1.5 times more compared to Krasnogvardejskiy district. However, the level of productivity of tillage in Krasnogvardeyskiy district retains its position. And this is despite the fact the share of moderately and severely eroded less productive lands are on 5.9 and $8.3 \%$ more than in Valuiskiy and Veidelevskiy districts accordingly.

Thus, as a result of agrolandscapes transformation in Krasnogvardeisky district for the period of landscape agricultural systems influence from 1986 to 2010, croplands annually produce on average an additional $0.56 \mathrm{t} / \mathrm{ha}$ of dry matter of crops yield. This is on $24.8 \%$ higher compared with the level of productivity, regarded as intermediate between Valuiskiy and Veydelevskiy districts.

The growth of plants biomass plays an important role for maintaining and improving of soil fertility. At the same time the accumulation of organic matter in soil is very important. First, good by weight development of roots firmly holds the soil from erosion. Besides, in annual cycle of their turning organic soil matter is formed, this change was fixed in studied period of time ( 24 years) in humus content increase on $0.4 \%$ (abs.). Our studies showed that, stubble-root residues mass of crops in reformed agrolandscapes is logically higher - in average on $16.5 \%$.

With the exception of tillage under protective afforestation the annual increase of dry matter of the farm lands' main products in Krasnogvardeisky district consists 76.5 thousand tons per year. The total amount of dry matter of aboveground and underground crops phytomass of reformed agrolandscapes is 980.4 thousand tons. This is $16.0 \%$ higher than the productivity agrolandscapes without development of landscape agricultural systems.

It is known that natural grasslands after their improvement (amelioration) increase their productivity on 2-4 times (Cherkasov, 1986). In case of Krasnogvardeyskiy district increase of forage lands productivity from 0.68 $\mathrm{t} / \mathrm{ha}$ to $1.81 \mathrm{t} / \mathrm{ha}$ of heys was observed, in conversion to dry matter gives gain in $0.80 \mathrm{t} / \mathrm{ha}$.

Production potential of reformed on landscape basis agroecosystems is not limited by farm land productivity increase because it also includes forest crop phytomass and phytomass of grassland vegetation of protective afforestation. Moreover, the main part of woody vegetation presents all year round agrolandscape element. Acting for many years protective forest strips have a unique features. Over the years, they do not lose their value, but on the contrary, every year it increases.

As a result of developing landscape agricultural systems in Krasnogvardeiskiy district were created 8700 ha of forest ranges. According to the Forest Management of Belgorod region species composition stands as follows: birch is $11 \%$, oak plantations account for $6 \%$, poplar - $14 \%$, acacia - 30, pine - 20 ash -16 , maple and other species - $3 \%$.

Based on the ratio of the species composition and the data obtained in determining the parameters of the average tree of each species in a protective afforestation Krasnogvardeiskiy district, we calculated the total stock of phytomass dry matter of forest belts. While determining the biological capacity of agrolandscapes the annual productivity of grassland vegetation in protective afforestation also considered.

The data presented in Table 4 show that during the development of landscape agricultural systems the biological capacity of agrolandscapes was 2.2 times higher (excluding fauna) than the biological capacity of the same landscapes without the development of a new type of agricultural systems. This has a positive effect on 
increasing the circulation of elements - the exchangeable biological capacity increased by $32 \%$.

Table 4. Output of phytomass dry matter while development of landscape agricultural systems in Krasnogvardeiskiy district of Belgorod region, thousands ton

\begin{tabular}{|c|c|}
\hline Index & Phytomass \\
\hline 1. Without development LASs (plant and feed production) & 845.2 \\
\hline 2. While development LASs, excluding agricultural lands under forest strips & 980.4 \\
\hline 3. Protective forest planting, & 836.1 \\
\hline including current year's growth & 107.9 \\
\hline 4. Grassland vegetation of forest strips, & 81.8 \\
\hline including current year's growth & 27.0 \\
\hline Total while development of landscape agricultural systems, & 1898.3 \\
\hline including exchangeable biological capacity & 1115.3 \\
\hline
\end{tabular}

Thus, while the development of landscape agricultural systems the improving of soil fertility is accompanied by increased accumulation and intensification of metabolism processes. The intensity and extent of the biological cycles and energy flows determine the efficiency of crop production.

\subsection{Bioenergy Potential}

Soil fertility, in particular humus content as a result of its inherent buffering controls flows of natural and anthropogenic energy in the direction of renewable sources share increasing and reducing of non-renewable. In other words, the efficiency of use, for instance, such as mineral fertilizers on the more fertile, humus soils is much higher, as facts show.

As established by Kotlyarova (1995), decrease of winter wheat yield on eroded soil in comparison with non-eroded it without fertilizers consisted $0.27 \mathrm{t} / \mathrm{ha}(9 \%)$. Optimum dose of mineral fertilizer application $\left(\mathrm{N}_{60} \mathrm{P}_{60}\right)$ has increased gap in yield on slight eroded and non-eroded soils up to $0.46 \mathrm{t} / \mathrm{ha}(14 \%)$.

The studies done by Kotlyarova showed that while application of optimal doses of fertilizers on non-eroded and slight eroded soils (in first case $\mathrm{N}_{60} \mathrm{P}_{60} \mathrm{~K}_{60}$, in second $-\mathrm{N}_{90} \mathrm{P}_{90} \mathrm{~K}_{90}$ ) difference in yield on the plain and slope is decreasing: from $20.8 \%$ without fertilizers up to $10.5 \%$ against optimal doses of fertilizers. However, even applying higher doses on slope lands the yield level of non-eroded soils wasn't reached.

Kershenz and Shultz (2005) marks an evident difference in optimal doses of nitrogen fertilizers which are necessary for getting equal yield in soils with different content of organic matter; the difference comprises 40 $\mathrm{kg} / \mathrm{ha}$. Maximum difference between variants has reached $81 \mathrm{~kg} / \mathrm{ha}$.

Increasing production costs per unit of agricultural products raise the problem of resource and energy conservation, as well as evaluating the coefficient of efficiency (COE) of using natural and human resources in different variants of development of agricultural production. Despite the importance of economic indicators of production, such as, for example, the yield in terms of value per unit area, profitability, labor productivity, cost and other more objective analysis of the efficiency that characterizes the intensity of the binding of energy by agroecosystems is energetical. It allows to measure on a comparable basis the cost of living and past labor, resources of different origin, which does not depend on price policy, etc.

Traditional energy analysis of the effectiveness of farming technologies is carried out by correlating the energy input, accumulated by products, and expenses of anthropogenic energy expended on its production. By such analysis beyond the evaluation system, the energy resource of agro-ecosystem main component - soil is left, as well as protective afforestation, improving agroecological state of agrolandscape and assisting in crop yield increase.

Quantitative estimation of using level of natural and human resources, prediction of the direction of agroecosystems development is possible because of resource and environmental evaluation on the bioenergy basis (Volodin et al., 1999). In accordance with this method we have calculated bioenergetics and ecological-economic indicators (Table 5). 
Table 5. Bioenergy potential and indexes of resources-ecological evaluation of agrolandscapes

\begin{tabular}{|c|c|c|}
\hline \multirow[b]{2}{*}{ Value } & \multicolumn{2}{|c|}{ Agrolandscape } \\
\hline & without LASs & with LASs \\
\hline Bioenergy potential of the territory, GJ/ha & 2544.1 & 2878.2 \\
\hline \multicolumn{3}{|l|}{ Bioenergy indexes } \\
\hline Energy efficiency of $\mathrm{PAR}_{\mathrm{vp}}$ & $4.4 \cdot 10^{-2}$ & $6.3 \cdot 10^{-2}$ \\
\hline Energy efficiency of soil organic matter & $2.9 \cdot 10^{-2}$ & $3.9 \cdot 10^{-2}$ \\
\hline Total anthropogenic energy efficiency & 6.0 & 8.0 \\
\hline \multicolumn{3}{|l|}{ Ecological economic indexes } \\
\hline Agriculture ecosystem capacity index per monetary expenses, mJ-day/rub. & $6.0 \cdot 10^{-2}$ & $7.9 \cdot 10^{-2}$ \\
\hline Agriculture ecosystem capacity index per labor expenses unit, mJ-day/per.-hour. & 52.3 & 59.6 \\
\hline
\end{tabular}

Energy indicator allowed to estimate in complex soil and plant resources of agrolandscape is a value of its ecological capacity (Volodin, 2000). Ecological capacity of agrolandscapes is ability to accept and transform the certain quantity of matter and energy providing its stable functioning in set mode. It includes bioenergy potential of the territory and energy of mineral fertilizer elements able to transform in functioning of agrioecosystems. Research done by Podlesnykh (2003), showed that energy of labile soil nutrients in ecological capacity of agrolandscapes with chernozem soils consist small percentage. That's why we are most interested in bioenergy potential of the territory determining main part of ecological capacity (Volodin, 2000) and defined by quantity of phytomass and soil organic matter energy.

The table shows clearly that all bioenergy and ecological-economical indexes of agrolandscapes with the development landscape agricultural systems is higher then without them. Excesses consist from $14.0 \%$ (productivity per unit of labor costs) to $43.2 \%$ (ratio of energy use PAR). Thus, the reformation of agro-ecosystems on the landscape basis increases efficiency of using natural and human resources, and thus leads to significant energy and resource conservation.

\subsection{Balance of Carbon in Landscape Agricultural Systems}

The development of landscape agricultural systems has increased the utilization coefficient of PAR and, consequently, assimilation ability of agroecosystems and the amount of transformed carbon, which means the absorbed carbon dioxide. The obtained quantitative characteristics of the organic matter state you can use for perspectives evaluation of landscape agricultural systems as a means which increases so-called carbon sink.

In natural ecosystems prevails carbon sink, or the value of the $\mathrm{CO}_{2}$ balance is close to zero. Soils play an important role in the global carbon cycle and can be associated with the absorption and emission to the atmosphere. According to international rates the store of organic carbon in world soils is about 1350 billion tons, which corresponds to approximately $80 \%$ of the total content of this element in all components of terrestrial ecosystems, including vegetation (Romanovskaya, 2006).

Agrocenosis traditionally considered as a major source of $\mathrm{CO}_{2}$ and other greenhouse gases in the atmosphere due to violations of ecosystem carbon cycle, leading to mineralization of soil organic matter (Larionova, Rozanova, Evdokimov, \& Ermolaev, 2002; Romanovskaya, 2006; Lopes de Gerenu, Kurganova, Ermolaev, \& Kusyakov, 2009). The basic elements of landscape agricultural systems, as meadow and forest amelioration, traditionally considered as techniques increasing the carbon accumulation in ecosystem and soil. Quantitative evaluations of carbon balance in such ecosystems and accumulation rates of humus in soil are very few and very relevant. Such object existence as Krasnogvardeiskiy district in Belgorod region with complete development of all LASs elements on the whole district area gives an unique possibility to consider in total reformed agrolandscapes as carbon deposit reservoir.

Transfer of atmospheric carbon in plant biomass and its long-term storage in reservoir of soil organic matter (SOM) with minimal risk of an immediate return to the atmosphere is denoted as "carbon dioxide sequestration". Humus, as the most stable part of SOM is the major reservoir of sequester carbon.

Commonly used evaluation methods of soil carbon sequestration - is calculation of organic matter balance and determine changes in total content $\mathrm{C}_{\text {org }}$ in soil and its resources for any period. Our researches showed that annual resultant humus balance in soils is changing from $0.02 \%$ of humus per year in total in Krasnogvardeiskiy 
district to $0.05 \%$ and even more in particular cases. Thus, only for the topsoil $(0-20 \mathrm{~cm})$ of agricultural lands throughout the district the amount of annual carbon sequestration will be $0.26 \mathrm{t} / \mathrm{ha}$. However, the possibility of carbon sequestration to specific farms should be considered separately, since they may reach $0.64 \mathrm{t} / \mathrm{ha}$ or more. Besides, protective afforestation on a scale of carbon sequestration and especially on its long-term accumulation significantly contribute carbon budget of biosphere. Annual carbon sequestration in steady state conditions of forest belts functioning is estimated at average about 1 t/ha per year (Stetsenko, Sidorenko, Luzhetskaya, Shatailov, \& Kulevskiy, 2002; Mukhin \& Voronin, 2007). Consequently, forest plants contribution in Krasnogvardeyskiy district is $0.07 \mathrm{t} / \mathrm{ha}$ per unit of agricultural land.

Thus, the total carbon sequestration of formed ecologically sustainable agricultural landscapes ranging consists from 0.33 to $0.71 \mathrm{t} / \mathrm{ha}$ and above that very little inferior to forest systems, which are recognized as the most reliable and capacious with high speed carbon accumulation in the biogeocoenose. The number of stored carbon dioxide is determined by multiplying the amount of carbon on 3.66 (molar weight of carbon dioxide molecule compared with the carbon atom).

Consequently, the potential for depositing of carbon dioxide in Krasnogvardeiskiy district consists 1.2-2.6 t/ha, which means the total amount 158.4-343.2 thousands tons of $\mathrm{CO}_{2}$. Taking into account the current price per one ton of carbon dioxide emissions of U.S. \$ 10-15 (Bobylev, 2009) investment resources attraction from the global carbon market will be 1,6-5,2 million U.S. dollars.

In addition, activities on reduction of GNG emission are accompanied by decreasing traditional atmosphere pollutions emissions $\left(\mathrm{SO}_{2}, \mathrm{NO}_{\mathrm{x}}\right.$, solid matters) that has a beneficial effect on human health and the environment. The fact is also confirmed by our research. In landscape agricultural systems happens the improvement of environmental state in general, as evidenced by a study on the stability of plant Betula pendula Roth. development. In reformed agrolandscapes in Krasnogvardeiskiy district index of fluctuating asymmetry of leafs is characterized by the state of its environment as a "minor deviation from the norm" and is equal to 0.043 - it is significantly lower than in neighboring Valuiskiy (0.048) and Veydelevskiy (0.049) districts where environmental quality is evaluated on lower class as "average deviation from the norm". Environment state in many ways determines human welfare and health. This effect is confirmed not only by essential decrease in average value of respiratory diseases in population of developed LASs in 1.5-2.0 times (in some age groups it is even more), but by positive trend of its dynamic for the last years (Kotlyarova, 2010). The determining fact as showed correlation analysis in decreasing of respiratory diseases level appear to be ecological frame of landscape agricultural systems - system of protective afforestation.

\section{Conclusion}

Landscape agricultural systems contribute not only to stop the intensive development of erosion processes, but also to restore soil fertility. Increasing of agricultural crops productivity in LASs happens not only due to the preservation and improvement of soil fertility, but also due to creating the best for their growth and development of agro-ecological conditions and their adaptive placement. As a result croppage and agrolandscape stability are increased, especially in environmentally stressful conditions.

Increase in 2.2 times of agrolandscapes production potential in landscape agricultural systems was formed by the increased output of organic matter agrocenosis as well as phytomass of woody and herbaceous vegetation of protective afforestation. This helps to increase the exchangeable biological capacity of agroecosystem by $32 \%$. Strengthening accumulation processes and intensification of metabolism during the development of landscape agricultural systems increases the efficiency of crop production. All bioenergy and ecological-economical indexes of agrolandscapes with the development landscape agricultural systems is higher then without them. The reformation of agro-ecosystems on the landscape basis increases efficiency of using natural and human resources, and thus leads to significant energy and resource conservation.

Rising of assimilation potential of reformed agroecosystems on the basis of landscape system allow to consider them not as $\mathrm{CO}_{2}$ source (as opposed to traditional) in the atmosphere but as deposit carbon reservoir, the capacity of which reaches $0.71 \mathrm{t} / \mathrm{ha}$ per year, it is slightly inferior to the most efficient forest systems ( $1 \mathrm{t} / \mathrm{ha} \mathrm{per} \mathrm{year).}$

Creation of an ecological skeleton by means of protective afforestation increases a biological variety of plant species, including rare of the Belgorod region Red book. In the system of protective wood plantings the risk of occurrence and development of deflation decreases, the maintenance of dust suspensions of harmful substances in the air undesirable to the human reduces. These make it possible to have a beneficial effect on human health and the environment.

Thus, landscape agricultural systems are a factor of positive human influence on soil fertility, productivity of 
agricultural lands, species diversity, biological capacity, energy potential of agro-ecosystems, environment and population health.

\section{Acknowledgements}

This paper is prepared in the memory of the academician of Russian Academy of Agrarian Sciences O.G. Kotlyarova, untimely deceased in January 2012. Thanks to her dedicated work over a lifetime on creating environmentally sustainable and highly productive agrolandscapes our research was made possible.

\section{References}

Atlas «Natural resources and ecological status of Belgorod region». Educational cartographic guide. (2005). Belgorod, Russia.

Bobylev, S. N. (2009). Forest resources and economy. Bulletin on the way to stable development of Russia, 47, 4-9.

Cherkasov, G. N. (1986). Recommendations on improving natural forage lands on ravine-plantations and slope lands of Central Chernozem zone. Kursk, Russia.

Cherniavskih, V. I., \& Kotlyarova, E. G. (2009). Multicomponent mixtures of annuals in a part of fodder crop rotation on sloping lands of the Belgorod region. Zemledelie, 8, 42-44.

Eskov, A. I., Lukin, S. M., \& Tarasov, S. I. (2005). Methodological approaches to the assessment of soil humus with prolonged use of various fertilizer systems. In: Methods of soil organic matter (pp. 111-134). Moscow, Russia: Agricultural Academy - State VNIPTIOU.

Karpachevskiy, L. O. (1981). Forest and forest soils. Moscow, Russia: Forestry.

Kershens, M., \& Shults, E. (2005). Soil organic substance: dynamic - reproduction - economically and ecologically proved indicators. Research methods of soil organic substance. Moscow, Russia: Russian Agricultural Academy - GNU VNIPTIOU.

Kotlyarova, E. G. \& Cherniavskih, V. I. (2008). Expansion of the biological diversity in landscape systems. Journal of Agricultural Sciences, 4, 21-24.

Kotlyarova, E. G. (2010). Respiratory Disease of the Population in Anthropogenically Formed Landscapes. Russian Agricultural Sciences, 36(5), 356-358. http://dx.doi.org/10.3103/S1068367410050113

Kotlyarova, O. G. (1995). Landscape agricultural system in Central Chernozem zone. Belgorod, Russia: BelGSXA.

Kotlyarova, O. G. (2004). Anthropogenic formation of environmentally sustainable agrolandscapes. Belgorod, Russia: BelGSXA.

Lal, R., \& Stewart, B. A. (1990). Soil Degradation. New York: Springer-Verlag.

Larionova, A. A., Rozanova, L. N., Evdokimov, И. V., \& Ermolaev, A. M. (2002). Carbon balance in natural and anthropogenic ecosystems of forest-steppe. Pochvovedenie, 2, 177-185.

Lopes de Gerenu, V. O., Kurganova, I. N., Ermolaev, A. M., \& Kusyakov, Y. V. (2009). Organic carbon pool change while self regeneration of arable black soils. Agrochemistry, 5, 5-12.

Losovoy, A. D. (1996). Forest subsidiary book. Voronezh, Russia.

Milashchenko, N. Z., Sokolov, O. A., Bryson, T., \& Chernikov, V. A. (2000). Sustainable development of agricultural landscape. Pushchino, Russia: ONTI PNT PAN.

Models of adaptive landscape agricultural systems for main natural agricultural areas of the country. (2005). Kursk, Russia: VNIISandSPE.

Mukhin, V. A., \& Voronin, P. Y. (2007). Micetogenic decomposition of woody tissue and carbon discharge into forest ecosystems. Ecology, 1, 24-29.

Myers, N. (1993). Gaia: An Atlas of Planet Management. New York: Anchor and Doubleday, Garden City.

Nemtsev, S. N., Sabitov, M. M., \& Nikitin, S. N. (2009). Soil conservation in the Ulyanovsk region. Zemledelie, $7,12-13$.

Pimentel, D., Harvey, C., Resosudarmo, P., Sinclair, K., Kurz, D., McNair, M., ... Blair, R. (1995). Environmental and economic cost of soil erosion and conservation benefits. Science, 267, 1117-1123. http://dx.doi.org/10.1126/science.267.5201.1117 
Podlesnykh, I. V. (2003). Ecological capacity and performance features of agrolandscapes with blackearth soils of forest-steppe in Central Black earth region. productivity (Unpublished master's thesis). Kursk GSXA. Kursk. Russia.

Romanenko, G. A. (2007). Problems of degradation, protection and revegetation of agriculture areas of Russia. Moscow, Russia: VNIIA.

Romanovskaya, A. A. (2006). Organic carbon in soils of fallow land in Russia. Pochvovedenie, 1, 52-61.

Shelganov, I. I., Domanov, N. M., Solovichenko, V. D., \& Potryasaev, A. A. (2009). Long-term steady-state experiments in solving the problem of improving soil fertility and productivity of agriculture. Zemledelie, 7 , $16-18$.

Shevtsova, L., Romanenkov, V., Sirotenko, O., Smith, P., Smith, J. U., Leech, P., ... Radionova, V. (2003). Effect of natural and agricultural factors on long-term soil organic matter dynamics in arable soddy-podzolic soils - modeling and observation. Geoderma, 116, 165-189. http://dx.doi.org/10.1016/S0016-7061(03)00100-9

Solovichenko, V. D. (2005). Fertility and rational utilization of soils in Belgorod region. Belgorod, Russia: Otchiy kray.

Stetsenko, A. V., Sidorenko, B. N., Luzhetskaya, H. V., Shatailov, V. V., \& Kulevskiy, A. V. (2002). GNG absorption by forest belts on agricultural lands. Moscow, Russia: Reform-press.

Verzilin, V. V. (2004). Biological factors of fertility reproduction in black soil in steppe agrocenosis CCZ. (Unpublished doctoral dissertation). VNIISandZPE RASXN. Kursk. Russia.

Volodin, V. M. (2000). Ecological principles of evaluation and usage of soils fertility. Moscow, Russia: TSINAO.

Volodin, V. M., Eremin, R. F., Fedorchenko, A. E., \& Ermakova, A. A. (1999a). Methods of resourse-ecologycal estimation of farming efficiency on bioenergy basis. Kursk, Russia: YUMEKS. 